\title{
Adsorption of Dyes Reactive Blue 221, N Blue RGB and Acid Blue MTR on Two Different Samples of Activated Carbon
}

\author{
Rita Kant ${ }^{1}$ and V. K. Rattan ${ }^{2, \uparrow}$ \\ ${ }^{1}$ University Institute of Fashion Technology, Panjab University, Chandigarh 160014, India \\ ${ }^{2}$ University Institute of Chemical Engineering and Technology, Panjab University, Chandigarh 160014, India \\ ^e-mail: vkrattanpu@yahoo.com \\ (Received February 28, 2010; Accepted August 5, 2010)
}

\begin{abstract}
Removal of dyes Reactive Blue 221, N Blue RGB and Acid Blue MTR using two different samples of activated carbon by static batch method was studied. Experimental data on optical density of solutions at different concentrations ranging from 10 to $100 \mathrm{mg} / \mathrm{L}$ and of solutions after adsorption on activated carbon samples were measured. Calibration curves were plotted and the amount of dye $\mathrm{q}_{\mathrm{e}}$ adsorbed was calculated. The data was fitted to Langmuir and Freundlich isotherms for two different carbon samples and different concentration and $\mathrm{pH}$ values. Constants were calculated from the slope and intercept values of the isotherms. Coefficient of correlation $\mathrm{R}^{2}$ and Standard Deviation SD were also noted. The data fitted well to the isotherms. Carbon sample $\mathrm{C}_{1}$ showed higher potential to adsorb all the three dyes. Adsorption was higher at lower concentrations. Carbon sample $\mathrm{C}_{2}$ showed better adsorption in acidic $\mathrm{pH}$ as compared to in alkaline $\mathrm{pH}$. From the analysis of the data capacity of $\mathrm{C}_{1}$ and $\mathrm{C}_{2}$ to remove the dyes from water have been compared.
\end{abstract}

Keywords : Adsorption, Reactive Blue 221, N blue RGB, Acid blue MTR, Activated carbon, Isotherms

\section{Introduction}

Color has always been very important in nature and environment and it continues to play a very significant role in imparting interesting hues to plants, animals and in the lives of mankind. After the dyeing process the residual and unspent substances are usually discharged into the environment. Amongst the different industrial wastewaters with different types of color-causing substances, synthetic textile organic dye wastes occupy a prominent position [1]. The colloidal matter can often be carcinogenic; show allergic reactions; interfere with photosynthesis; clog the pores of the soil; be a breading ground for bacteria and viruses. It is important to remove these pollutants from the waste waters before their final disposal [2-4]. Adsorption of organics from solutions on activated carbon is one of the oldest and widespread applications of this material. Earlier studies of activated carbon adsorption were carried out on fatty acids and later extended to a large number of dyes [5].

Nevine Kamal Amin [6] investigated the use of activated carbons prepared from pomegranate peel for the removal of direct blue dye from aqueous solution. Azza Khaled et al. [7]. studied the removal of Direct N Blue-106 from textile dye effluent using activated carbon from agricultural waste material: orange peel. Equilibrium adsorption isotherm for the removal of basic dye (Methylene Blue) from aqueous solution using bituminous coal-based activated carbon has been examined by Emad $\mathrm{N}$ et al. [8]. The effect of experimental parameters, namely, $\mathrm{pH}$ and adsorbent particle size were studied and the maximum adsorptive capacity was determined. B. H. Hameed [9] researched on activated carbon prepared from non-wood forest product waste using it as adsorbent for the removal of methylene blue dye from an aqueous solution.

Abhiti Purai et al. [10] tested the ability of cow dung ash, an eco friendly and low cost adsorbent, without any pretreatment to remove color from textile dyes. The adsorption was achieved under different $\mathrm{pH}$ and adosrbate concentration.

The present work forms a part of continuing study to compare the adsorptive capacity of different samples of activated carbon and low cost adsorbents.

\section{Experimental}

Samples of Granular Activated Carbon $\mathrm{C}_{1}$ and $\mathrm{C}_{2}$ used were obtained from Brillex Chemical Ltd. Punjab and Industrial Carbon Pvt. Ltd., Gujarat. Surface area of GAC C used in the study was $950 \mathrm{~m}^{2} / \mathrm{g}$ and that of $\mathrm{GAC} \mathrm{C}_{2}$ was $600 \mathrm{~m}^{2} / \mathrm{g}$. Bulk density of the two was 500 550 and 600 $650 \mathrm{~g} / \mathrm{L}$ respectively. The ash content was $6 \%$ in $\mathrm{C}_{1}$ and $5 \%$ in $\mathrm{C}_{2}$. From the stock solution of the dyes dilutions were made with distilled water to make different concentrations. Optical density of all the solutions was measured on a spectrophotometer (ELICO make, wavelength range 200 
Table 1. Concentration of Dyes $\left(C_{e}\right)$ and Amount of Dye Adsorbed Per Gram of the Adsorbent $\left(q_{e}\right)$ on $C_{1} \& C_{2}$ at Different $p H$

\begin{tabular}{|c|c|c|c|c|c|c|c|c|c|c|c|c|}
\hline \multirow[t]{2}{*}{$\begin{array}{c}\text { Dye } \\
\text { Name }\end{array}$} & \multicolumn{4}{|c|}{$\begin{array}{c}\text { Reactive Blue } 221 \\
\text { pH }\end{array}$} & \multicolumn{4}{|c|}{$\begin{array}{c}\text { N Blue RGB } \\
\text { pH }\end{array}$} & \multicolumn{4}{|c|}{$\begin{array}{c}\text { Acid Blue MTR } \\
\text { pH }\end{array}$} \\
\hline & $\begin{array}{c}\mathrm{C}_{1} \\
5.49\end{array}$ & $\begin{array}{c}\mathrm{C}_{2} \\
5.49\end{array}$ & $\begin{array}{c}\mathrm{C}_{2} \\
3.43\end{array}$ & $\begin{array}{c}\mathrm{C}_{2} \\
9.27\end{array}$ & $\begin{array}{c}\mathrm{C}_{1} \\
5.20\end{array}$ & $\begin{array}{c}\mathrm{C}_{2} \\
5.20\end{array}$ & $\begin{array}{c}\mathrm{C}_{2} \\
3.74\end{array}$ & $\begin{array}{c}\mathrm{C}_{2} \\
8.01\end{array}$ & $\begin{array}{c}\mathrm{C}_{1} \\
6.51\end{array}$ & $\begin{array}{c}\mathrm{C}_{2} \\
6.51\end{array}$ & $\begin{array}{c}\mathrm{C}_{2} \\
3.80\end{array}$ & $\begin{array}{c}\mathrm{C}_{2} \\
8.69\end{array}$ \\
\hline$\overline{\mathrm{C}_{\mathrm{e}}(\mathrm{mg} / \mathrm{L})}$ & & & & & & & & & & & & \\
\hline 10 & 0.32 & 0.25 & 0.26 & 0.20 & 0.40 & 0.22 & 0.27 & 0.21 & 0.35 & 0.24 & 0.26 & 0.19 \\
\hline 20 & 0.51 & 0.41 & 0.49 & 0.31 & 0.59 & 0.38 & 0.45 & 0.32 & 0.51 & 0.37 & 0.47 & 0.34 \\
\hline 30 & 0.67 & 0.60 & 0.60 & 0.45 & 0.73 & 0.55 & 0.71 & 0.44 & 0.68 & 0.59 & 0.63 & 0.51 \\
\hline 40 & 0.89 & 0.79 & 0.80 & 0.58 & 0.90 & 0.71 & 0.93 & 0.57 & 0.87 & 0.79 & 0.86 & 0.72 \\
\hline 50 & 1.07 & 0.99 & 1.03 & 0.73 & 1.02 & 0.87 & 1.12 & 0.70 & 1.05 & 0.99 & 1.07 & 0.96 \\
\hline 60 & 1.22 & 1.08 & 1.14 & 0.92 & 1.15 & 1.01 & 1.31 & 0.88 & 1.21 & 1.20 & 1.33 & 1.17 \\
\hline 70 & 1.33 & 1.13 & 1.23 & 1.02 & 1.28 & 1.15 & 1.51 & 1.03 & 1.39 & 1.40 & 1.56 & 1.37 \\
\hline 80 & 1.42 & 1.19 & 1.27 & 1.06 & 1.42 & 1.24 & 1.70 & 1.19 & 1.59 & 1.58 & 1.80 & 1.55 \\
\hline 90 & 1.45 & 1.22 & 1.30 & 1.07 & 1.49 & 1.31 & 1.84 & 1.31 & 1.73 & 1.75 & 1.97 & 1.67 \\
\hline 100 & 1.49 & 1.24 & 1.35 & 1.10 & 1.53 & 1.39 & 1.85 & 1.33 & 1.85 & 1.77 & 2.01 & 1.70 \\
\hline
\end{tabular}

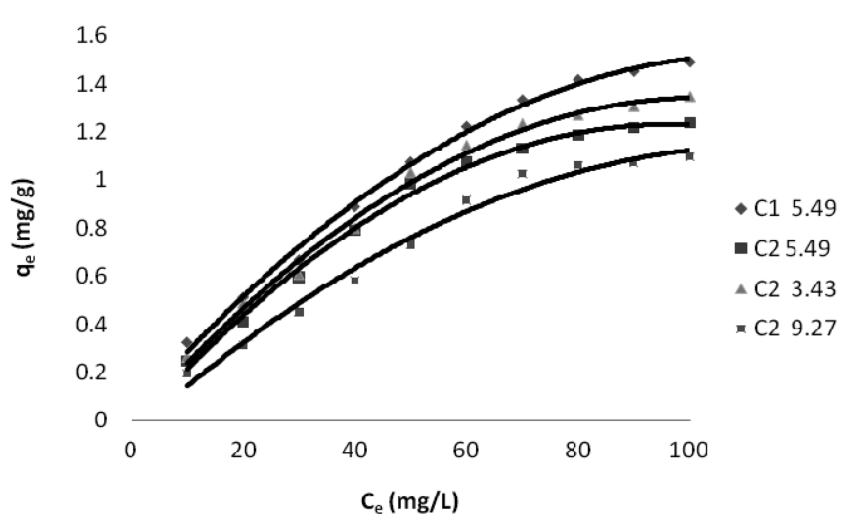

Fig. 1. Adsorption Isotherm for dye Reactive Blue 221 on $\mathrm{C}_{1}$ \& $\mathrm{C}_{2}$ at different $\mathrm{pH}$ values.

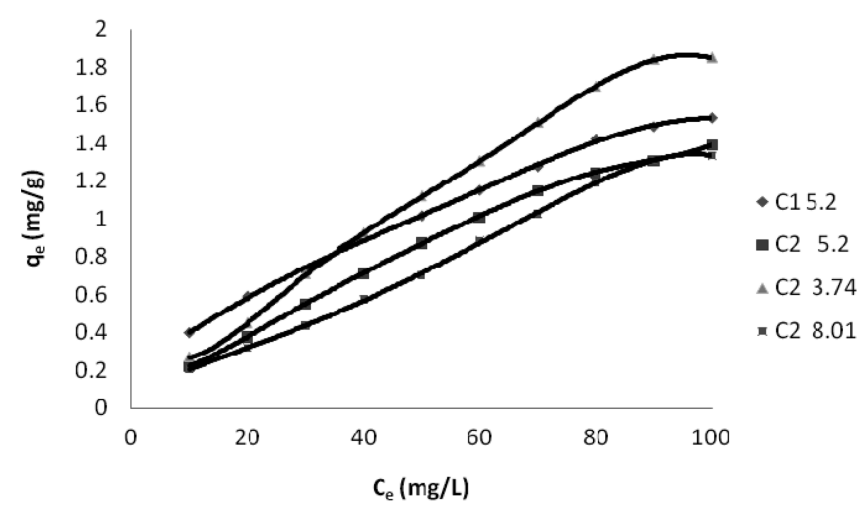

Fig. 2. Adsorption Isotherm for dye $\mathrm{N}$ Blue $\mathrm{RGB}$ on $\mathrm{C}_{1} \& \mathrm{C}_{2}$ at different $\mathrm{pH}$ values.

$900 \mathrm{~nm})$. One gram of activated carbon was placed in each $50 \mathrm{~mL}$ solution of 10 to $100 \mathrm{ppm}$. The solutions were shaken and kept in a thermostat for $24 \mathrm{~h}$. The samples were then filtered and analyzed spectrophotometrically.

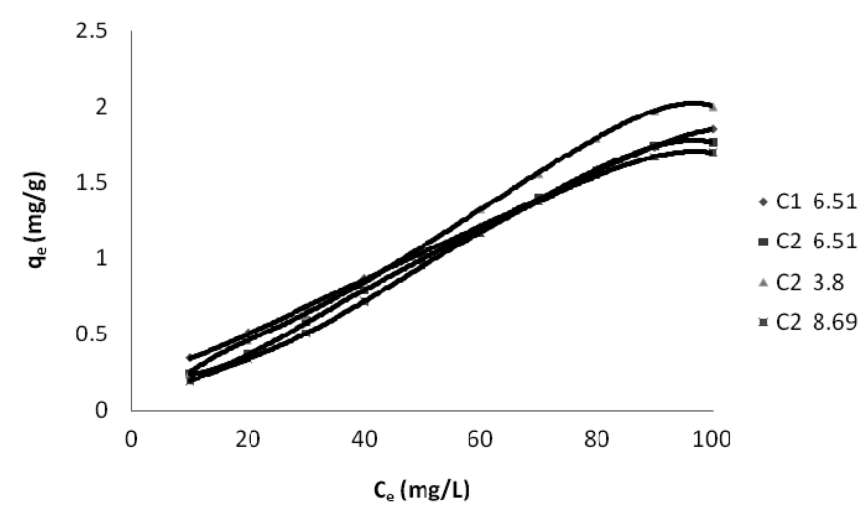

Fig. 3. Adsorption Isotherm for dye Acid Blue MTR on $C_{1}$ \& $\mathrm{C}_{2}$ at different $\mathrm{pH}$ values.

\section{Results and Discussion}

\subsection{Effect of initial dye concentration}

Table 1 and Figs. 1 3 show the amount qe of Reactive Dye Blue 221, N Blue RGB and Acid Blue MTR adsorbed by $\mathrm{C}_{1}$ and $\mathrm{C}_{2}$ samples of granulated activated carbon at various $\mathrm{pH}$ values and various ppm concentrations. It can be seen that $\mathrm{q}_{\mathrm{e}}$ on $\mathrm{GAC} \mathrm{C}_{1}$ and $\mathrm{C}_{2}$ was higher at lower ppm concentration as compared to the adsorption at higher ppm concentration with the adsorbent dose being kept constant for all the three dyes . At $10 \mathrm{ppm}$ concentration and initial (slightly acidic) $\mathrm{pH}$ of $5.49 \mathrm{C}_{1}$ adsorbed $0.645 \mathrm{mg} / \mathrm{g}$ of the dye Reactive Blue 221 and $\mathrm{C}_{2}$ adsorbed $0.495 \mathrm{mg} / \mathrm{g}$. At $100 \mathrm{ppm}$ concentration the adsorption of Reactive Blue 221 was $2.978 \mathrm{mg} / \mathrm{g}, 2.470 \mathrm{mg} /$ $\mathrm{g}$, on $\mathrm{C}_{1}$ and $\mathrm{C}_{2}$ respectively at the same $\mathrm{pH}$. This pattern of higher adsorption on lower ppm concentrations was observed for all the three reactive dyes. $\mathrm{C}_{1}$ showed better adsorption as compared to adsorption on $\mathrm{C}_{2}$. 
Table 2. Values of Different Constants for Polynomial Fit Data

\begin{tabular}{|c|c|c|c|c|c|c|c|c|c|c|c|c|}
\hline \multirow[t]{2}{*}{$\begin{array}{l}\text { Dye } \\
\text { Name }\end{array}$} & \multicolumn{4}{|c|}{$\begin{array}{c}\text { Reactive Blue } 221 \\
\text { pH }\end{array}$} & \multicolumn{4}{|c|}{$\begin{array}{c}\text { N Blue RGB } \\
\text { pH }\end{array}$} & \multicolumn{4}{|c|}{$\begin{array}{c}\text { Acid Blue MTR } \\
\text { pH }\end{array}$} \\
\hline & $\begin{array}{c}\mathrm{C}_{1} \\
5.49\end{array}$ & $\begin{array}{c}\mathrm{C}_{2} \\
5.49\end{array}$ & $\begin{array}{c}\mathrm{C}_{2} \\
3.43\end{array}$ & $\begin{array}{c}\mathrm{C}_{2} \\
9.27\end{array}$ & $\begin{array}{c}\mathrm{C}_{1} \\
5.20\end{array}$ & $\begin{array}{c}\mathrm{C}_{2} \\
5.20\end{array}$ & $\begin{array}{c}\mathrm{C}_{2} \\
3.74\end{array}$ & $\begin{array}{c}\mathrm{C}_{2} \\
8.01\end{array}$ & $\begin{array}{c}\mathrm{C}_{1} \\
6.51\end{array}$ & $\begin{array}{l}\mathrm{C}_{2} \\
6.51\end{array}$ & $\begin{array}{c}\mathrm{C}_{2} \\
3.80\end{array}$ & $\begin{array}{c}\mathrm{C}_{2} \\
8.69\end{array}$ \\
\hline A & 2.639 & -0.048 & 1.04767 & 2.26633 & 5.06333 & 1.03967 & 1.98067 & 3.59933 & 4.10967 & 2.85933 & 3.91067 & 2.604 \\
\hline $\mathrm{B}_{1}$ & 0.35455 & 0.46783 & 0.4137 & 0.11642 & 0.31495 & 0.32011 & 0.3098 & 0.02532 & 0.26567 & 0.13414 & 0.09604 & 0.05349 \\
\hline $\mathrm{B}_{2}$ & 0.00145 & -0.00143 & $-4.82 \mathrm{E}-05$ & 0.00472 & $4.02 \mathrm{E}-04$ & $7.80 \mathrm{E}-04$ & 0.0036 & 0.00563 & 0.00209 & 0.00633 & 0.00784 & 0.00835 \\
\hline $\mathrm{B}_{3}$ & $-2.31 \mathrm{E}-05$ & $-8.04 \mathrm{E}-06$ & $-1.55 \mathrm{E}-05$ & $-3.96 \mathrm{E}-05$ & $-9.74 \mathrm{E}-06$ & $-1.32 \mathrm{E}-05$ & $-3.15 \mathrm{E}-05$ & $-3.55 \mathrm{E}-05$ & $-1.44 \mathrm{E}-0$ & $-4.39 \mathrm{E}-05$ & $-5.13 \mathrm{E}-05$ & $-5.73 E-05$ \\
\hline$r^{2}$ & 0.9985 & 0.99499 & 0.99359 & 0.99614 & 0.99835 & 0.99961 & 0.99836 & 0.99829 & 0.99954 & 0.99896 & 0.99847 & 0.99985 \\
\hline SD & 0.39819 & 0.62087 & 0.7568 & 0.51775 & 0.38997 & 0.1959 & 0.56562 & 0.41698 & 0.27311 & 0.4416 & 0.60985 & 0.16964 \\
\hline
\end{tabular}

\subsection{Effect of $\mathrm{pH}$}

Adsorption of the three dyes has been studied at different $\mathrm{pH}$ for carbon sample $\mathrm{C}_{2}$ and at one $\mathrm{pH}$ for $\mathrm{C}_{1} \cdot \mathrm{C}_{2}$ was greatly effected by change in $\mathrm{pH}$ of the aqueous solution as can be seen in Tables 1 and Figs. 1 3. Amount of dye adsorbed $\mathrm{q}_{\mathrm{e}}$ on $\mathrm{C}_{2}$ in acidic $\mathrm{pH}$ is higher at all ppm concentrations as compared to adsorption in a lesser acidic and an alkaline environment. At an acidic $\mathrm{pH}$ of 3.43 at $10 \mathrm{ppm}$ concentration $\mathrm{C}_{2}$ adsorbed $5.21 \mathrm{mg} / \mathrm{g}$ of the dye Reactive Blue 221. In an alkaline $\mathrm{pH}$ of 9.27 the same $\mathrm{C}_{2}$ adsorbed only $3.90 \mathrm{mg} / \mathrm{g}$ leaving behind a good number of free adsorption sites on the adsorbent. The same pattern could be observed on N Blue RGB and Acid Blue MTR. At $10 \mathrm{ppm}$ concentration $\mathrm{C}_{2}$ adsorbed $5.40 \mathrm{mg} / \mathrm{g}$ and $5.10 \mathrm{mg} / \mathrm{g}$ of $\mathrm{N}$ Blue RGB and Acid Blue MTR at acidic $\mathrm{pH}$. At alkaline $\mathrm{pH}$ the adsorption was only $4.10 \mathrm{mg} / \mathrm{g}$ and $3.80 \mathrm{mg} / \mathrm{g}$ respectively at the same $10 \mathrm{ppm}$ concentration of $\mathrm{N}$ Blue RGB and Acid Blue MTR.

$\mathrm{C}_{1}$ as compared to $\mathrm{C}_{2}$ shows higher adsorption at initial $\mathrm{pH}$.It also shows better adsorption than $\mathrm{C}_{2}$ did in acidic environment.

\subsection{Data fit for Simple isotherms}

It can be seen from Figs. 1 3 that the experimental data fitted well to polynomial equation of the type:

$$
\mathrm{q}_{\mathrm{e}}=\mathrm{A}+\mathrm{B}_{1} \mathrm{C}_{\mathrm{e}}+\mathrm{B}_{2} \mathrm{C}_{\mathrm{e}}{ }^{2}+\mathrm{B}_{3} \mathrm{C}_{\mathrm{e}}^{3}
$$

The constants and standard deviation are given in Table 2. Comparative adsorption of all the dyes on $\mathrm{C}_{1} \& \mathrm{C}_{2}$ at various $\mathrm{pH}$ values is shown in Figs. 1 3. Maximum dye removal of $\mathrm{N}$ Blue RGB was observed on $\mathrm{C}_{1}$ at acidic $\mathrm{pH}$ 5.2. Least adsorption efficiency of all the three dyes was shown by $\mathrm{C}_{2}$ at alkaline $\mathrm{pH}$ values. On the whole $\mathrm{C}_{1}$ exhibited most favourable adsorption at initial $\mathrm{pH}$ values as compare to $\mathrm{C}_{2}$. $\mathrm{C}_{2}$ showed maximum adsorption at acidic $\mathrm{pH}$.

\subsection{Langmuir isotherm at various $\mathrm{pH}$}

The experimental data was fitted to linear form of

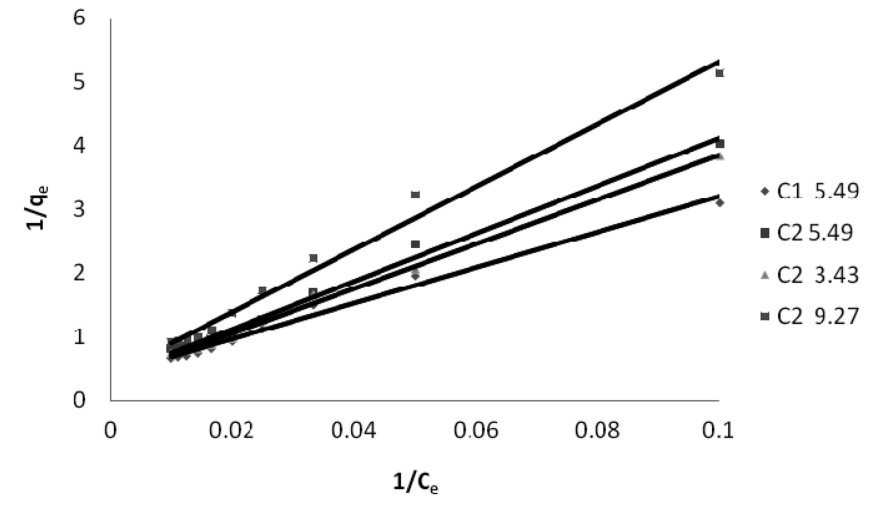

Fig. 4. Langmuir Isotherm for dye Reactive Blue 221 on $C_{1}$ \& $\mathrm{C}_{2}$ at different $\mathrm{pH}$ values.

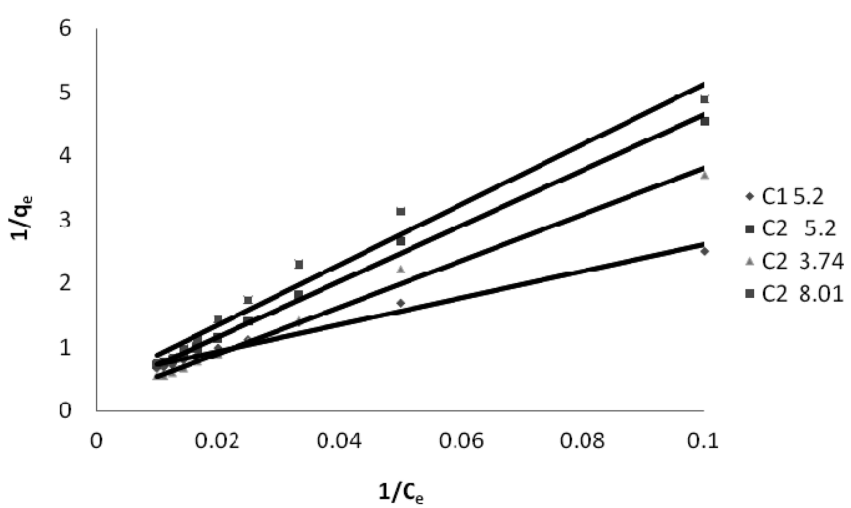

Fig. 5. Langmuir Isotherm for dye $N$ Blue $R G B$ on $C_{1} \& C_{2}$ at different $\mathrm{pH}$ values.

Langmuir isotherm for all the $\mathrm{pH}$ values of the three dyes and for the two samples of GAC.

$\mathrm{Q}$ and $\mathrm{b}$ the Langmuir constants were calculated from the straight line slope and intercept of linear plot between $1 / \mathrm{q}_{\mathrm{e}}$ and $1 / \mathrm{C}_{\mathrm{e}}$ as shown in Fig. 4 to 6.

Table 3 gives the values of Langmuir constants $\mathrm{Q}$ and $\mathrm{b}$ along with the values of $\mathrm{r}^{2}$ and SD for all the three dyes and their varied $\mathrm{pH}$ values and for the two samples of GAC, $\mathrm{C}_{1}$ and $\mathrm{C}_{2}$. Value of constants $\mathrm{Q} \mathrm{b}$ signify good adsorption of all 


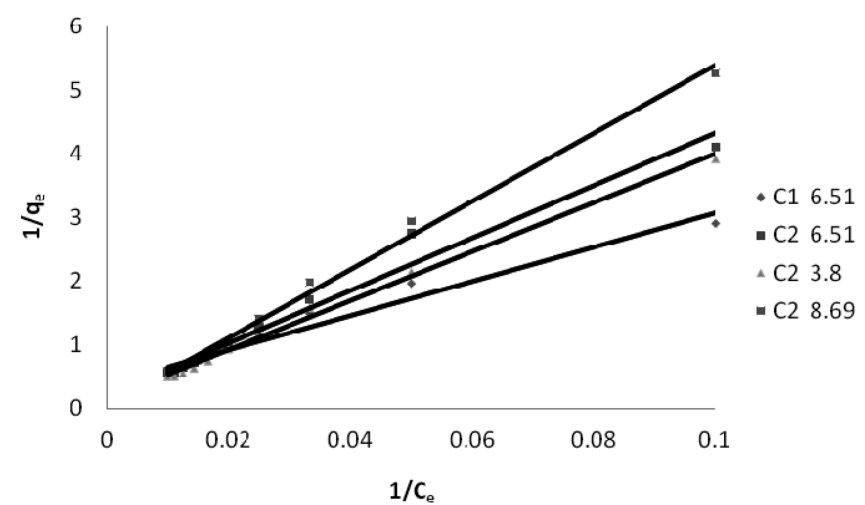

Fig. 6. Langmuir Isotherm for dye Acid Blue MTR on $\mathrm{C}_{1} \& \mathrm{C}_{2}$ at different $\mathrm{pH}$ values.

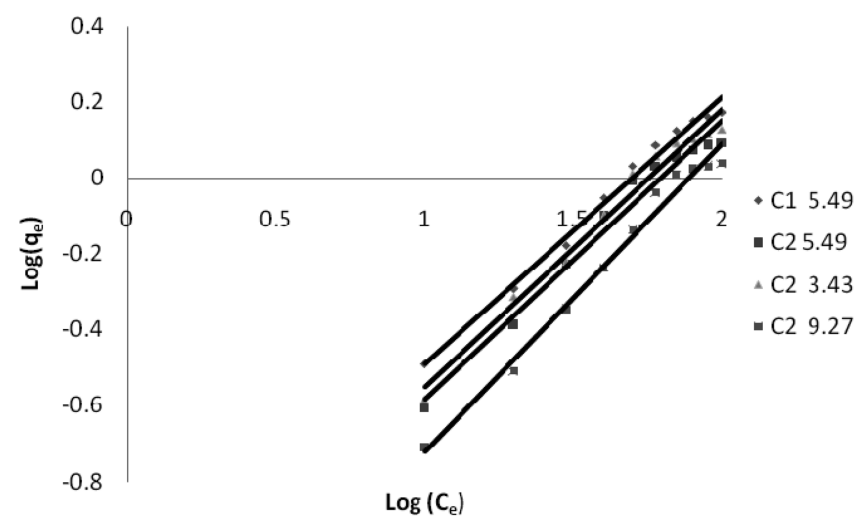

Fig. 7. Freundlich Isotherm for dye Reactive Blue 221 on $\mathrm{C}_{1} \&$ $\mathrm{C}_{2}$ at different $\mathrm{pH}$ values.

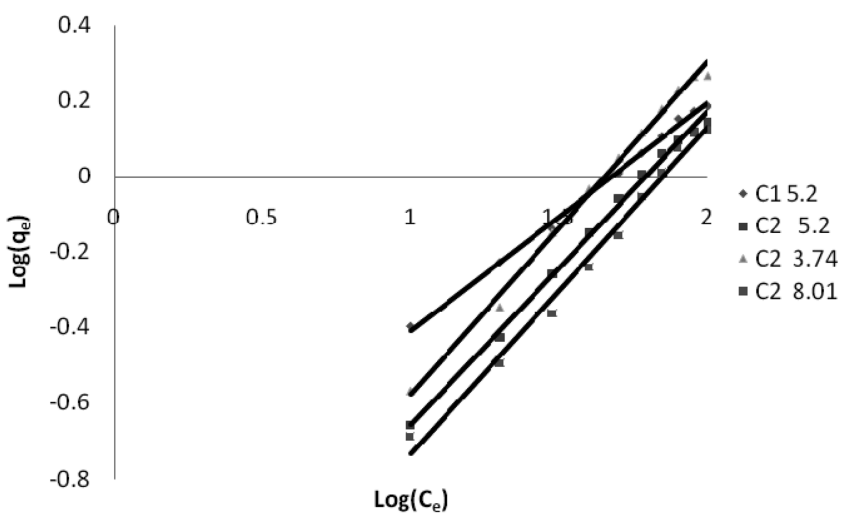

Fig. 8. Freundlich Isotherm for dye $N$ Blue RGB on $C_{1} \& C_{2}$ at different $\mathrm{pH}$ values.

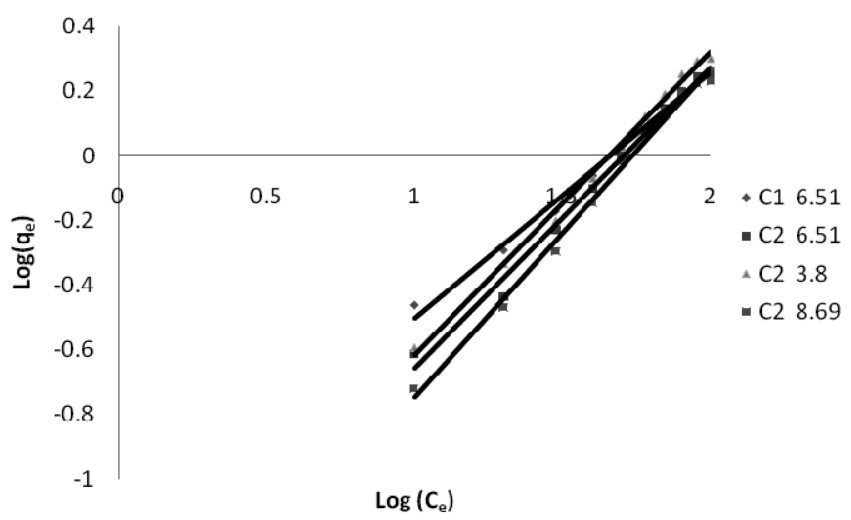

Fig. 9. Freundlich Isotherm for dye Acid Blue MTR on $\mathrm{C}_{1} \& \mathrm{C}_{2}$ at different $\mathrm{pH}$ values.

Table 3. Values of Different Constants for Langmuir Isotherm at Various pH Values

\begin{tabular}{|c|c|c|c|c|c|c|c|c|c|c|c|c|}
\hline \multirow[t]{2}{*}{$\begin{array}{l}\text { Dye } \\
\text { Name }\end{array}$} & \multicolumn{4}{|c|}{$\begin{array}{c}\text { Reactive Blue } 221 \\
\text { pH }\end{array}$} & \multicolumn{4}{|c|}{$\begin{array}{c}\text { N Blue RGB } \\
\text { pH }\end{array}$} & \multicolumn{4}{|c|}{$\begin{array}{c}\text { Acid Blue MTR } \\
\text { pH }\end{array}$} \\
\hline & $\begin{array}{c}\mathrm{C}_{1} \\
5.49\end{array}$ & $\begin{array}{c}\mathrm{C}_{2} \\
5.49\end{array}$ & $\begin{array}{c}\mathrm{C}_{2} \\
3.43\end{array}$ & $\begin{array}{c}\mathrm{C}_{2} \\
9.27\end{array}$ & $\begin{array}{c}\mathrm{C}_{1} \\
5.20\end{array}$ & $\begin{array}{c}\mathrm{C}_{2} \\
5.20\end{array}$ & $\begin{array}{c}\mathrm{C}_{2} \\
3.74\end{array}$ & $\begin{array}{c}\mathrm{C}_{2} \\
8.01\end{array}$ & $\begin{array}{l}\mathrm{C}_{1} \\
6.51\end{array}$ & $\begin{array}{c}\mathrm{C}_{2} \\
6.51\end{array}$ & $\begin{array}{c}\mathrm{C}_{2} \\
3.80\end{array}$ & $\begin{array}{c}\mathrm{C}_{2} \\
8.69\end{array}$ \\
\hline $\mathrm{Q}$ & 46.361 & 52.219 & 51.520 & 41.859 & 38.402 & 59.277 & 109.29 & 42.123 & 44.17 & 72.993 & 114.15 & 230.95 \\
\hline b & 0.015 & 0.011 & 0.012 & 0.010 & 0.024 & 0.008 & 0.005 & 0.010 & 0.018 & 0.007 & 0.005 & 0.002 \\
\hline$r^{2}$ & 0.964 & 0.983 & 0.978 & 0.976 & 0.961 & 0.989 & 0.983 & 0.969 & 0.954 & 0.945 & 0.986 & 0.977 \\
\hline SD & 0.008 & 0.007 & 0.008 & 0.011 & 0.006 & 0.007 & 0.007 & 0.012 & 0.008 & 0.014 & 0.007 & 0.012 \\
\hline
\end{tabular}

Table 4. Values of Different Constants for Freundlich Isotherm at Various pH Values

\begin{tabular}{|c|c|c|c|c|c|c|c|c|c|c|c|c|}
\hline \multirow[t]{2}{*}{$\begin{array}{c}\text { Dye } \\
\text { Name }\end{array}$} & \multicolumn{4}{|c|}{$\begin{array}{c}\text { Reactive Blue } 221 \\
\text { pH }\end{array}$} & \multicolumn{4}{|c|}{$\begin{array}{c}\text { N Blue RGB } \\
\text { pH }\end{array}$} & \multicolumn{4}{|c|}{$\begin{array}{c}\text { Acid Blue MTR } \\
\text { pH }\end{array}$} \\
\hline & $\begin{array}{c}\mathrm{C}_{1} \\
5.49\end{array}$ & $\begin{array}{c}\mathrm{C}_{2} \\
5.49\end{array}$ & $\begin{array}{c}\mathrm{C}_{2} \\
3.43\end{array}$ & $\begin{array}{c}\mathrm{C}_{2} \\
9.27\end{array}$ & $\begin{array}{c}\mathrm{C}_{1} \\
5.20\end{array}$ & $\begin{array}{c}\mathrm{C}_{2} \\
5.20\end{array}$ & $\begin{array}{c}\mathrm{C}_{2} \\
3.74\end{array}$ & $\begin{array}{c}\mathrm{C}_{2} \\
8.01\end{array}$ & $\begin{array}{c}\mathrm{C}_{1} \\
6.51\end{array}$ & $\begin{array}{l}\mathrm{C}_{2} \\
6.51\end{array}$ & $\begin{array}{c}\mathrm{C}_{2} \\
3.80\end{array}$ & $\begin{array}{c}\mathrm{C}_{2} \\
8.69\end{array}$ \\
\hline $\mathrm{K}_{\mathrm{F}}$ & 1.288 & 0.955 & 1.049 & 0.576 & 1.920 & 0.655 & 0.683 & 0.495 & 1.108 & 0.516 & 0.565 & 0.344 \\
\hline $\mathrm{N}$ & 1.425 & 1.357 & 1.369 & 1.225 & 1.648 & 1.208 & 1.128 & 1.149 & 1.322 & 1.075 & 1.069 & 0.984 \\
\hline$r^{2}$ & 0.987 & 0.974 & 0.981 & 0.985 & 0.997 & 0.997 & 0.995 & 0.989 & 0.992 & 0.990 & 0.994 & 0.993 \\
\hline SD & 0.027 & 0.040 & 0.034 & 0.034 & 0.011 & 0.016 & 0.021 & 0.030 & 0.023 & 0.032 & 0.236 & 0.029 \\
\hline
\end{tabular}


the three dyes on $\mathrm{C}_{1}$ as compared to $\mathrm{C}_{2}$ at initial $\mathrm{pH}$. It also indicates a better adsorption at acidic $\mathrm{pH}$ on $\mathrm{C}_{2}$.

\subsection{Freundlich isotherm at various $\mathrm{pH}$}

The linear plots of $\log \mathrm{q}_{\mathrm{e}}$ and $\log \mathrm{C}_{\mathrm{e}}$ for Freundlich isotherm are shown in Figs. 7 9. Table 4 shows the Freundlich constants $\mathrm{K}_{\mathrm{F}}$ and $\mathrm{n}$ calculated from the slope and intercept of $\log \mathrm{q}_{\mathrm{e}}$ and $\log \mathrm{C}_{\mathrm{e}}$ along with $\mathrm{R}^{2}$ and SD. $\mathrm{K}_{\mathrm{F}}$ (parameter relative to adsorption capacity) and $\mathrm{n}$ (process intensity) were calculated. Values of constant $\mathrm{K}_{\mathrm{F}}$ indicate higher adsorption capacity on Carbon sample $\mathrm{C}_{1}$ as compared to $\mathrm{C}_{2}$.

\section{Conclusions}

Granulated Activated Carbon sample $\mathrm{C}_{1}$ and $\mathrm{C}_{2}$ can be effectively used for the removal of dyes from wastewater by adsorption. The present study shows that there is a decrease in percentage removal of dye of carbon per gram with increase in ppm concentration of the dye. Change in $\mathrm{pH}$ values showed higher adsorption at acidic $\mathrm{pH}$. The three dyes obeyed Langmuir and Freundlich isotherms. Langmuir isotherm gave a better fit. Carbon sample $\mathrm{C}_{1}$ showed high adsorption for all the three dyes.

\section{References}

[1] Vijayraghavan, N. S. Science Tech. Entrepreneur 1999, 7, 3.

[2] Mahajan, S. P. "Pollution Control in Process Industries", Summer Report, 5. IIT Bombay.

[3] Whitaker and Hillock; "Dyeing and Coal tar Dyestuff", $5^{\text {th }}$ ed., 1949, 1.

[4] Edwaed, M. "Developments in Waste Water Treatment Methods", 2003, 27.

[5] Bansal, M. "Removal of pollutants from industrial waste water using activated carbon", Ph. D. Thesis, Panjab University, Chandigarh, 1997, 2 \& 12.

[6] Amin, N. K. References and further reading may be available for this article. To view references and further reading you must purchase this article. J. Hazardous Materials 2009, 165, 52.

[7] Khaled, A.; Nemr, A. El; El-Sikaily, A.; Abdelwahab, O. J. Hazardous Materials 2009, 165, 100.

[8] Qada, Emad N. El Allen; Stephen, J.; Walker, M. Gavin Chem. Eng. J. 2006, 124, 103.

[9] Hameed, B. H.; Ahmad, A. L.; Latiff K. N. A. Dyes and Pigments 2007, 75, 143.

[10] Rattan, V. K.; Purai, Abhiti; Singh, Harminder; Manoochehri, Mahboobeh Carbon Letters 2008, $9,1$.

[11] Dega, Al; Y. Khraisheh, M. A. M.; Allen, S. J.; Ahmad, M. N. Water Research 2000, 34, 927. 